Check for updates

Cite this: RSC Adv., 2019, 9, 36334

\title{
A uniform few-layered carbon coating derived from self-assembled carboxylate monolayers capable of promoting the rate properties and durability of commercial $\mathrm{TiO}_{2} \uparrow$
}

\begin{abstract}
Meng Huang, ${ }^{a}$ Hui-Ling Zhu, ${ }^{b}$ Yong-Xin Qi, ${ }^{a}$ Ning Lun*a and Yu-Jun Bai (D) *a
The poor cyclability and rate property of commercial $\mathrm{TiO}_{2}\left(\mathrm{c}-\mathrm{TiO}_{2}\right)$ hinder its utilization in lithium-ion batteries (LIBs). Coating carbon is one of the ways to ameliorate the electrochemical performance. However, how to effectively form a uniform thin carbon coating is still a challenge. On the basis of the strong interaction of the $\mathrm{TiO}_{2}$ surface with carboxyl groups, herein a new tactic to achieve uniform and thin carbon layers on the $\mathrm{c}-\mathrm{TiO}_{2}$ particles was proposed. When mixing $\mathrm{c}-\mathrm{TiO}_{2}$ with citric acid containing carboxyl groups in deionized water, the high-affinity adsorption of $\mathrm{TiO}_{2}$ for carboxyl groups resulted in self-assembled carboxylate monolayers on the surface of $\mathrm{TiO}_{2}$ which evolved into a uniform few-layered amorphous carbon coating during carbonizing at $750{ }^{\circ} \mathrm{C}$. The product derived from the mixture of $\mathrm{C}^{-}$ $\mathrm{TiO}_{2}$ and citric acid with a mass ratio of $1: 0.3$ exhibits the optimal performance, revealing a high specific capacity (256.6 mA h g $\mathrm{m}^{-1}$ after 50 cycles at $0.1 \mathrm{~A} \mathrm{~g}^{-1}$ ) and outstanding cycling stability (retaining a capacity of $160.0 \mathrm{~mA} \mathrm{~h} \mathrm{~g}{ }^{-1}$ after 1000 cycles at $0.5 \mathrm{~A} \mathrm{~g}^{-1}$ ). The greatly enhanced capacity and cyclability correlate with the uniform few-layered carbon coating which not only ameliorates the electronic conductivity of $\mathrm{c}-\mathrm{TiO}_{2}$ but also avoids the reduction in ionic conductivity caused by thick carbon layers and redundant carbon.
\end{abstract}

Received 8th October 2019

Accepted 4th November 2019

DOI: $10.1039 / c 9 r a 08141 k$

rsc.li/rsc-advances

\section{Introduction}

The rapid development of electric vehicles, hybrid electric vehicles and large-scale renewable energy storage equipment has prompted the urgent need for low-cost and environmentally friendly energy storage systems. Li-ion batteries (LIBs) have gained great success recently in commerce on account of their high energy and power densities, good stability and safety., However, the electrode materials still face some intractable obstacles, mainly including low electronic and/or ionic conductivities, and unavoidable capacity decay during charging and discharging.

Insertion-type anodes, especially Ti-based oxides, exhibit high safety. $\mathrm{TiO}_{2}$ has a series of advantages, such as environmental benignity, abundance in the earth, low price, high chemical stability, low volume change $(<4 \%)$ and small structural strain in lithiation/delithiation process. ${ }^{3,4}$ Nevertheless,

${ }^{a}$ Key Laboratory for Liquid-Solid Structural Evolution and Processing of Materials (Ministry of Education), Shandong University, Jinan 250061, PR China. E-mail: byj97@sdu.edu.cn; lunning66@sdu.edu.cn; Fax: +86 531 88392315; Tel: +86 531 88392315

${ }^{b}$ School of Materials Science and Engineering, Shandong University of Science and Technology, Qingdao, 266590, PR China

$\dagger$ Electronic supplementary information (ESI) available. See DOI: 10.1039/c9ra08141k the low electronic conductivity and poor Li-ion conductivity are the main factors restricting its application in LIBs. ${ }^{5,6}$ To date, extensive explorations have been carried out to solve these issues by ion-doping, ${ }^{7}$ scaling down the particle size to nanometer for shortening Li-ion diffusion length, ${ }^{8,9}$ appropriately controlling to form novel morphology, ${ }^{10-12}$ and coating with conductive carbon materials, ${ }^{13-15}$ among which the last one is commonly simple and efficient to improve the electrochemical performance of $\mathrm{TiO}_{2}$. However, the $\mathrm{TiO}_{2}$ employed in the available investigations was mostly prepared by the precursors with high cost, regardless of the economy for applications.

Commercially available anatase $\mathrm{TiO}_{2}$ with low cost is conveniently fabricated by acid etching titanium ore. However the impurities in the commercial $\mathrm{TiO}_{2}\left(\mathrm{c}-\mathrm{TiO}_{2}\right)$ have serious effect on the electrochemical performance, ${ }^{\mathbf{1 6}}$ only several reports are concerning with the electrochemical performance of c- $-\mathrm{TiO}_{2}$. Sulfate radicals are the dominant impurities in $\mathrm{c}-\mathrm{TiO}_{2}$, which could be eliminated by heating the $\mathrm{c}-\mathrm{TiO}_{2}$ above $750{ }^{\circ} \mathrm{C}$. Furthermore, coating carbon at $750{ }^{\circ} \mathrm{C}$ with the carbon source of glucose could not only effectively remove the sulfate radicals but also greatly meliorate the electrochemical properties of c$\mathrm{TiO}_{2}$, achieving a capacity of $203.4 \mathrm{~mA} \mathrm{~h} \mathrm{~g}^{-1}$ after 250 cycles at $0.5 \mathrm{Ag}^{-1} \cdot{ }^{17}$ When the $\mathrm{c}-\mathrm{TiO}_{2}$ was coated with soft carbon derived from pitch, a capacity of $140.2 \mathrm{~mA} \mathrm{~h} \mathrm{~g}^{-1}$ was retained after 1000 cycles at $0.5 \mathrm{~A} \mathrm{~g}^{-1} \cdot{ }^{18}$ Thus the $\mathrm{c}-\mathrm{TiO}_{2}$ composited with carbon at 
temperatures above $750{ }^{\circ} \mathrm{C}$ could denote elevated specific capacities owing to the removal of the sulfate radicals and the improvement in electrical conductivity, but the cyclability is still unsatisfactory, possibly because of the difficulty in tailoring the uniform formation of the carbon coating around the $\mathrm{TiO}_{2}$ particles. The incomplete carbon coating could not isolate $\mathrm{TiO}_{2}$ from electrolyte, and the electronic conductivity could not be thoroughly revealed. Moreover, superfluous carbon also affects the rate performance and cycling stability of $\mathrm{TiO}_{2}$ on account of the poor performance of carbon materials at high current rate.

Due to the low volume variation during the lithiation/ delithiation in $\mathrm{TiO}_{2}$, the optimum carbon content is to form the uniform and thin coating as soon as possible, not only enhancing the electric conductivity but also facilitating Li-ion migration. How to effectively achieve the homogenous thin carbon coating is still a challenge.

According to a very recent report, ${ }^{19} \mathrm{TiO}_{2}$ could selectively absorb carboxylic acid due to the high-affinity adsorption resulted from the bidentate binding, leading to self-assembled carboxylate monolayers on the surface of $\mathrm{TiO}_{2}$. This strong adsorption phenomenon might find other applications besides self-cleaning and photocatalysis. In this work, citric acid (CA) with carboxyl groups was chosen as the carbon source to manufacture the carbon-coated $\mathrm{c}-\mathrm{TiO}_{2}$ at $750{ }^{\circ} \mathrm{C}$, aiming at to obtain uniform and thin carbon coating layers for optimizing the electrochemical performance of $\mathrm{c}-\mathrm{TiO}_{2}$. As expected, the rate performance and cycling stability were significantly raised by simply adjusting the mass ratio of $\mathrm{CA} / \mathrm{TiO}_{2}$, achieving a high specific capacity of $256.6 \mathrm{~mA} \mathrm{~h} \mathrm{~g} \mathrm{~g}^{-1}$ at $0.1 \mathrm{~A} \mathrm{~g}^{-1}$ and $168.2 \mathrm{~mA} \mathrm{~h} \mathrm{~g}^{-1}$ at $0.5 \mathrm{~A} \mathrm{~g}^{-1}$ even after 1000 cycles. The mechanism involved was discussed by virtue of several characterization methods.

\section{Experimental}

\subsection{Fabrication of $\mathrm{TiO}_{2} / \mathrm{C}$}

The $\mathrm{c}-\mathrm{TiO}_{2}$ (purity of $99.19 \mathrm{wt} \%, 0.5 \mathrm{wt} \% \mathrm{SO}_{4}{ }^{2-}$, specific surface area of $350 \mathrm{~m}^{2} \mathrm{~g}^{-1}$ ) was purchased from Panzhihua TaiDu Chemical Industry Co. Ltd, identical to that in our previous work.

The carbon-coated c- $\mathrm{TiO}_{2}$ was fabricated by two simple steps. (1) CA of 0.6, 0.9 and $1.2 \mathrm{~g}$ was dissolved in $50 \mathrm{~mL}$ deionized water separately, then $3.0 \mathrm{~g} \mathrm{c}-\mathrm{TiO}_{2}$ was added into each solution and magnetically stirred for $30 \mathrm{~min}$ in a crucible (i.e. the mass ratio for $\mathrm{CA} / \mathrm{c}-\mathrm{TiO}_{2}$ is $0.2,0.3$ and 0.4 one by one), the uniform mixtures were dried in an oven at $105{ }^{\circ} \mathrm{C}$ for $12 \mathrm{~h}$ to obtain the precursors. (2) The dried precursors were calcined in a horizontal tube furnace at $750{ }^{\circ} \mathrm{C}$ for $5 \mathrm{~h}$ (at a heating rate of $5{ }^{\circ} \mathrm{C} \min ^{-1}$ ) under $\mathrm{N}_{2}$ atmosphere. The calcination products were consecutively labeled as $\mathrm{TiO}_{2} / \mathrm{C}-20, \mathrm{TiO}_{2} / \mathrm{C}-30$ and $\mathrm{TiO}_{2} / \mathrm{C}$ 40 in terms of the mass percent of $\mathrm{CA} / \mathrm{c}-\mathrm{TiO}_{2}$.

\subsection{Characterization}

Crystal structure was identified by powder X-ray diffraction (XRD) in a Rigaku Dmax-2500 diffractometer with $\mathrm{Cu} \mathrm{K} \alpha$ radiation in $2 \theta$ range from 10 to $90^{\circ}$. Raman spectra (Lab-RAM
HR800 Raman spectroscope) were adopted to characterize carbon material using argon ion laser excitation with wavelength of $632.81 \mathrm{~nm}$. High-resolution transmission electron microscopy (HRTEM, JEOL JEM-2100 microscope) was employed to analyze microstructure. Carbon content was determined by thermogravimetric analysis (TGA) via heating the carbon-coated samples in air to $700{ }^{\circ} \mathrm{C}$ in a TGA/DSC1/1600 apparatus.

\subsection{Electrode preparation and performance test}

The electrochemical properties of $\mathrm{TiO}_{2} / \mathrm{C}$ were tested by assembling coin-type half cells (CR 2025) in a glove box filled with Ar atmosphere. The active substance, acetylene black and polyvinylidene difluoride were mixed according to a mass ratio of $8: 1: 1$ in solvent of $n$-methyl pyrrolidinone. The homogeneous mixture was coated on $\mathrm{Cu}$ foil followed by vacuum drying for $12 \mathrm{~h}$ at $120{ }^{\circ} \mathrm{C}$. The other cell components include counter electrode of Li foil, separator of Celgard 2300, electrolyte containing $1 \mathrm{M} \mathrm{LiPF}_{6}$ dissolved in ethyl carbonate and dimethyl carbonate with a volume ratio of $1: 1$.

Land CT2001A battery test systems were employed to evaluate the electrochemical performance in a potential range of 0.02-3.0 V (vs. $\left.\mathrm{Li} / \mathrm{Li}^{+}\right)$at $25{ }^{\circ} \mathrm{C}$. An IviumStat electrochemical workstation was adopted to test cyclic voltammogram (CV) between 0.02 and $3.0 \mathrm{~V}$ at a scanning rate of $0.3 \mathrm{mV} \mathrm{s}^{-1}$ and electrochemical impedance spectra (EIS) in a frequency range of $10^{-2}-10^{5} \mathrm{~Hz}$ with a signal amplitude of $3 \mathrm{mV}$.

\section{Results and discussion}

\subsection{TG/DTG curves and FTIR spectra for determining the interaction between $\mathrm{TiO}_{2}$ and $\mathrm{CA}$}

In order to determine the interaction between $\mathrm{TiO}_{2}$ and CA, TG/ DTG curves were measured in $\mathrm{N}_{2}$ atmosphere for the pristine CA and the precursor of $\mathrm{TiO}_{2} / \mathrm{C}-30$. For CA, the dominant weight loss around $200{ }^{\circ} \mathrm{C}$ is followed by a slight weight loss around $250{ }^{\circ} \mathrm{C}$ owing to the pyrolysis of CA (Fig. 1a), and the intensity ratio for the latter DTG peak to the former one is 0.072 . However, for the precursor of $\mathrm{TiO}_{2} / \mathrm{C}-30$, besides the weight loss around $200{ }^{\circ} \mathrm{C}$, another weight loss happened around $375{ }^{\circ} \mathrm{C}$ (Fig. 1b), and the intensity ratio for the two DTG peaks is 0.2569 . Apparently, the weight loss at the second stage for the $\mathrm{TiO}_{2} / \mathrm{C}-30$ precursor shifts to higher temperature, and the ratio is much high than that for CA, demonstration the strong interaction between $\mathrm{TiO}_{2}$ and CA due to the high-affinity adsorption of $\mathrm{TiO}_{2}$ surface for carboxyl groups, as reported in the literature. ${ }^{19}$ The self-assembled carboxylate monolayers on the surface of $\mathrm{TiO}_{2}$ facilitates to evolved into uniform few-layered carbon coating during subsequent carbonization at $750{ }^{\circ} \mathrm{C}$.

The interaction between $\mathrm{TiO}_{2}$ and CA was also confirmed by FTIR (Fig. 1c). In the spectra of $\mathrm{TiO}_{2} / \mathrm{C}-30$ precursor and c-TiO the broad peak around $400-900 \mathrm{~cm}^{-1}$ originates from the Ti-O bond of $\mathrm{TiO}_{2},{ }^{20}$ the adsorption peaks near 1200 and $1400 \mathrm{~cm}^{-1}$ from the $-\mathrm{OH}$ in citric acid, the peak around $1634 \mathrm{~cm}^{-1}$ from the surface hydroxyl group, and the adsorption bands in the region of $3000-3500 \mathrm{~cm}^{-1}$ from the vibration of the adsorbed 

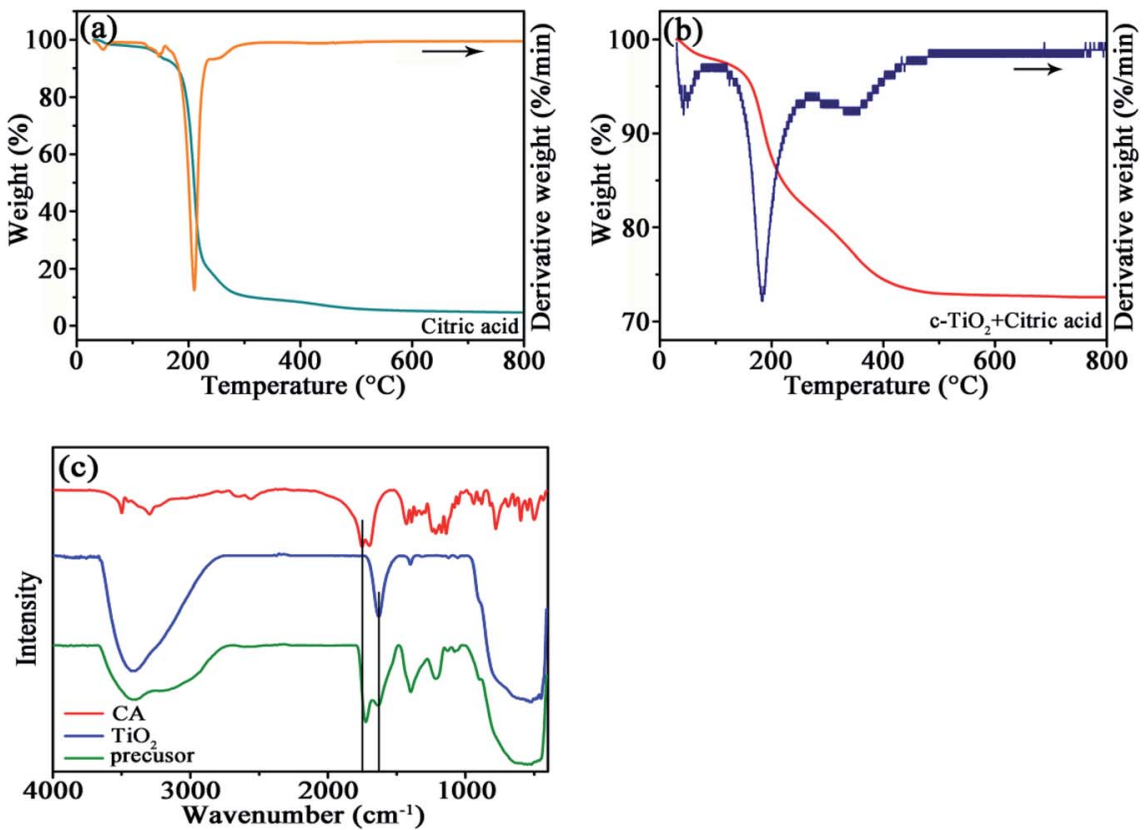

Fig. $1 \mathrm{TG} / \mathrm{DTG}$ curves of CA (a), $\mathrm{TiO}_{2} / \mathrm{C}$-30 precursor (b) at the heating rate of $10{ }^{\circ} \mathrm{C} \mathrm{min}^{-1}$ under $\mathrm{N}_{2}$ atmosphere, and (c) FTIR spectra of CA, TiO and $\mathrm{TiO}_{2} / \mathrm{C}-30$ precursor

water. ${ }^{21}$ The absorption band at $1751 \mathrm{~cm}^{-1}$ in CA is related to the $\mathrm{C}=\mathrm{O}$ from carboxyl groups. ${ }^{22,23}$ No deviation occurs for the adsorption peak of surface hydroxyl group at $1634 \mathrm{~cm}^{-1}$, whereas the position of $\mathrm{C}=\mathrm{O}$ bond in $\mathrm{TiO}_{2} / \mathrm{C}-30$ precursor shifts to $1724 \mathrm{~cm}^{-1}$, denoting the strong interaction between $\mathrm{TiO}_{2}$ and carboxyl group as observed in the TG/DTG curves.

\subsection{Structure and carbon content evaluation}

The XRD patterns (Fig. 2a) of $\mathrm{TiO}_{2}, \mathrm{TiO}_{2} / \mathrm{C}-20, \mathrm{TiO}_{2} / \mathrm{C}-30$, and $\mathrm{TiO}_{2} / \mathrm{C}-40$ calcined at $750{ }^{\circ} \mathrm{C}$ manifest similar diffractions to anatase $\mathrm{TiO}_{2}$ (JCPDS no. 71-1166). The peaks of bare $\mathrm{TiO}_{2}$ are narrower and stronger than those of $\mathrm{TiO}_{2} / \mathrm{C}$, demonstrating the
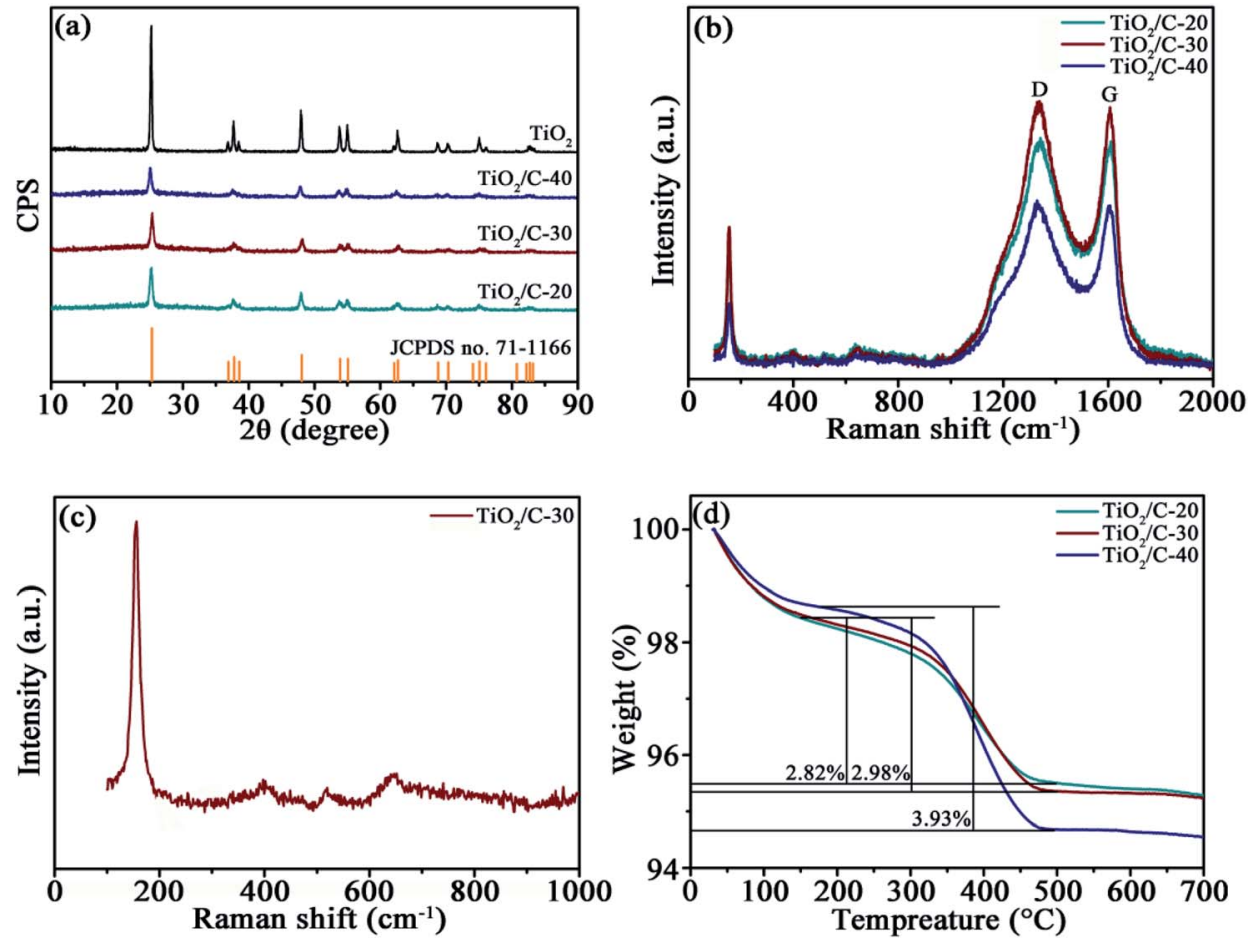

Fig. 2 (a) XRD patterns of $\mathrm{TiO}_{2}$ and $\mathrm{TiO}_{2} / \mathrm{C}$, (b) Raman spectra of $\mathrm{TiO}_{2} / \mathrm{C}$, (c) partially enlarged Raman spectrum $\mathrm{TiO} / \mathrm{C}-30$, and (d) $\mathrm{TG}$ curves of $\mathrm{TiO}_{2} / \mathrm{C}$. 
grain growth of $\mathrm{TiO}_{2}$ in the absence of carbon layer. Calculated by the Scherrer equation $D=K \lambda /(\beta \cos \theta)$, the average crystallite sizes are $38.7 \mathrm{~nm}$ for $\mathrm{TiO}_{2}, 14.7 \mathrm{~nm}$ for $\mathrm{TiO}_{2} / \mathrm{C}-20,13.9 \mathrm{~nm}$ for $\mathrm{TiO}_{2} / \mathrm{C}-30$ and $10.1 \mathrm{~nm}$ for $\mathrm{TiO}_{2} / \mathrm{C}-40$ in terms of the (101) plane, further confirming the hindered growth of $\mathrm{TiO}_{2}$ crystallites in the presence of carbon derived from CA. No distinct carbon diffractions could be identified due to the low content and amorphous structure, as evidenced by Raman spectra and TG analysis.

The presence of carbon in $\mathrm{TiO}_{2} / \mathrm{C}$ was corroborated by Raman spectra (Fig. 2b). The characteristic D (around $1341 \mathrm{~cm}^{-1}$ ) and $\mathrm{G}$ bands (around $1606 \mathrm{~cm}^{-1}$ ) represent amorphous and graphitized carbon, respectively. The relative intensity ratio $\left(I_{\mathrm{D}} / I_{\mathrm{G}}\right)$ of the two bands is 1.016 for $\mathrm{TiO}_{2} / \mathrm{C}-20,1.024$ for $\mathrm{TiO}_{2} / \mathrm{C}-30$ and 1.011 for $\mathrm{TiO}_{2} / \mathrm{C}-40$, manifesting the low graphitization degree of the CA-derived carbon. The partially enlarged Raman spectrum between $100-1000 \mathrm{~cm}^{-1}$ for $\mathrm{TiO}_{2} / \mathrm{C}-30$ (Fig. 2c) indicates the characteristic peaks at 154, 397, 521 and $631 \mathrm{~cm}^{-1}$ resulted from anatase $\mathrm{TiO}_{2} \cdot{ }^{\mathbf{2 4 , 2 5}}$

The carbon content was assessed by TGA at the heating rate of $10{ }^{\circ} \mathrm{C} \min ^{-1}$ under air atmosphere (Fig. 2d). The curves contain two weight loss stages; the one below $200{ }^{\circ} \mathrm{C}$ is attributed to the elimination of moisture absorbed on the samples, and the other one between 200 and $500{ }^{\circ} \mathrm{C}$ results from the combustion of carbon. Consequently, the carbon content is $2.82 \mathrm{wt} \%$ for $\mathrm{TiO}_{2} / \mathrm{C}-20,2.98 \mathrm{wt} \%$ for $\mathrm{TiO}_{2} / \mathrm{C}-30$, and $3.93 \mathrm{wt} \%$ for $\mathrm{TiO}_{2} / \mathrm{C}-40$.

\subsection{Microstructure examination}

The interaction of carbon with $\mathrm{TiO}_{2}$ was examined by TEM (Fig. 3). Homogeneous microstructure could be observed from the low magnification images (Fig. 3a, c and e). The highresolution images (Fig. 3b, d and f) illustrate the interplanar spacing of $0.35 \mathrm{~nm}$ which is consistent with that of the (101)
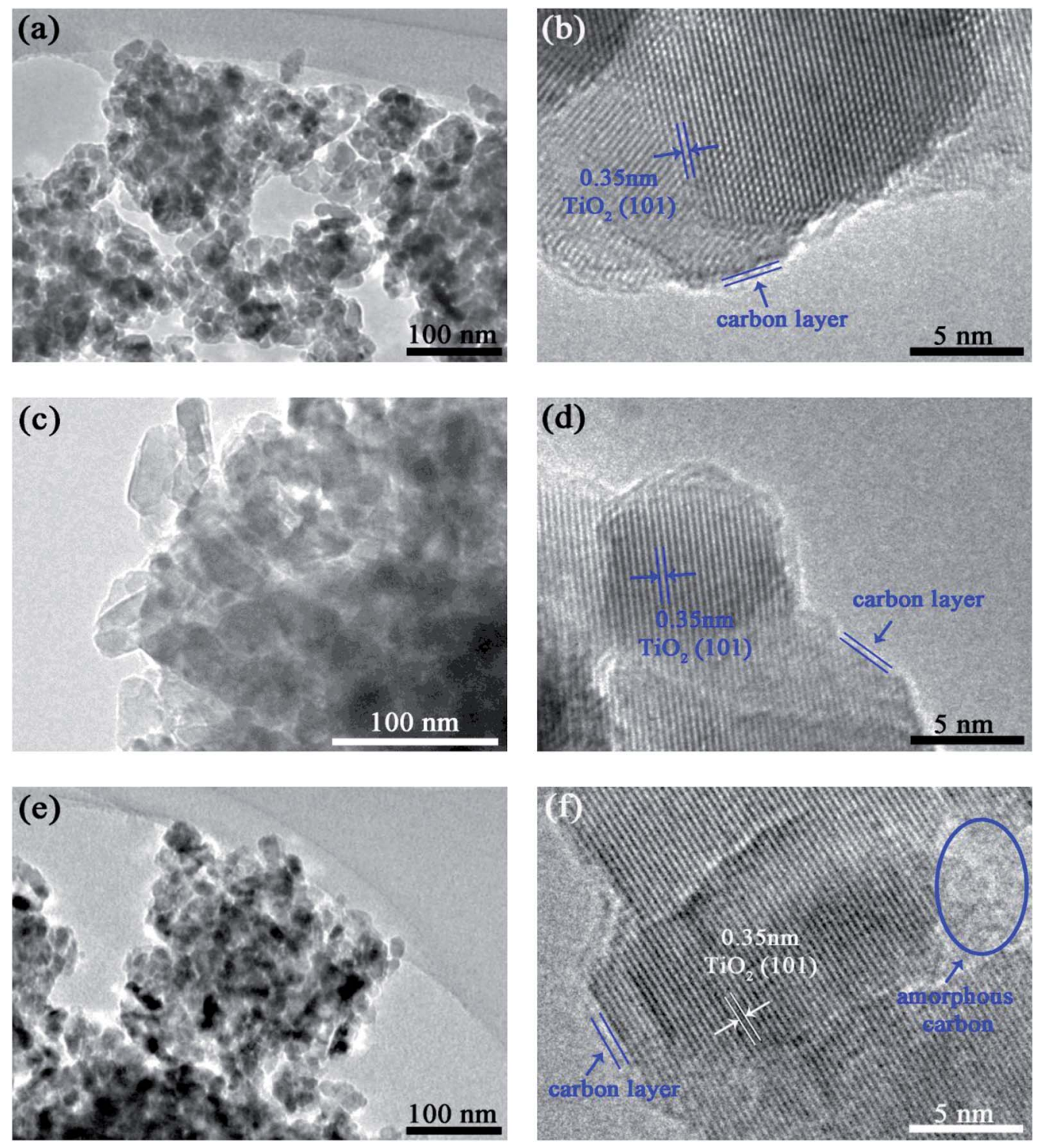

Fig. 3 TEM images of $\mathrm{TiO}_{2} / \mathrm{C}-20$ ( $a$ and b), $\mathrm{TiO}_{2} / \mathrm{C}-30$ (c and d), $\mathrm{TiO}_{2} / \mathrm{C}-40$ (e and f). 

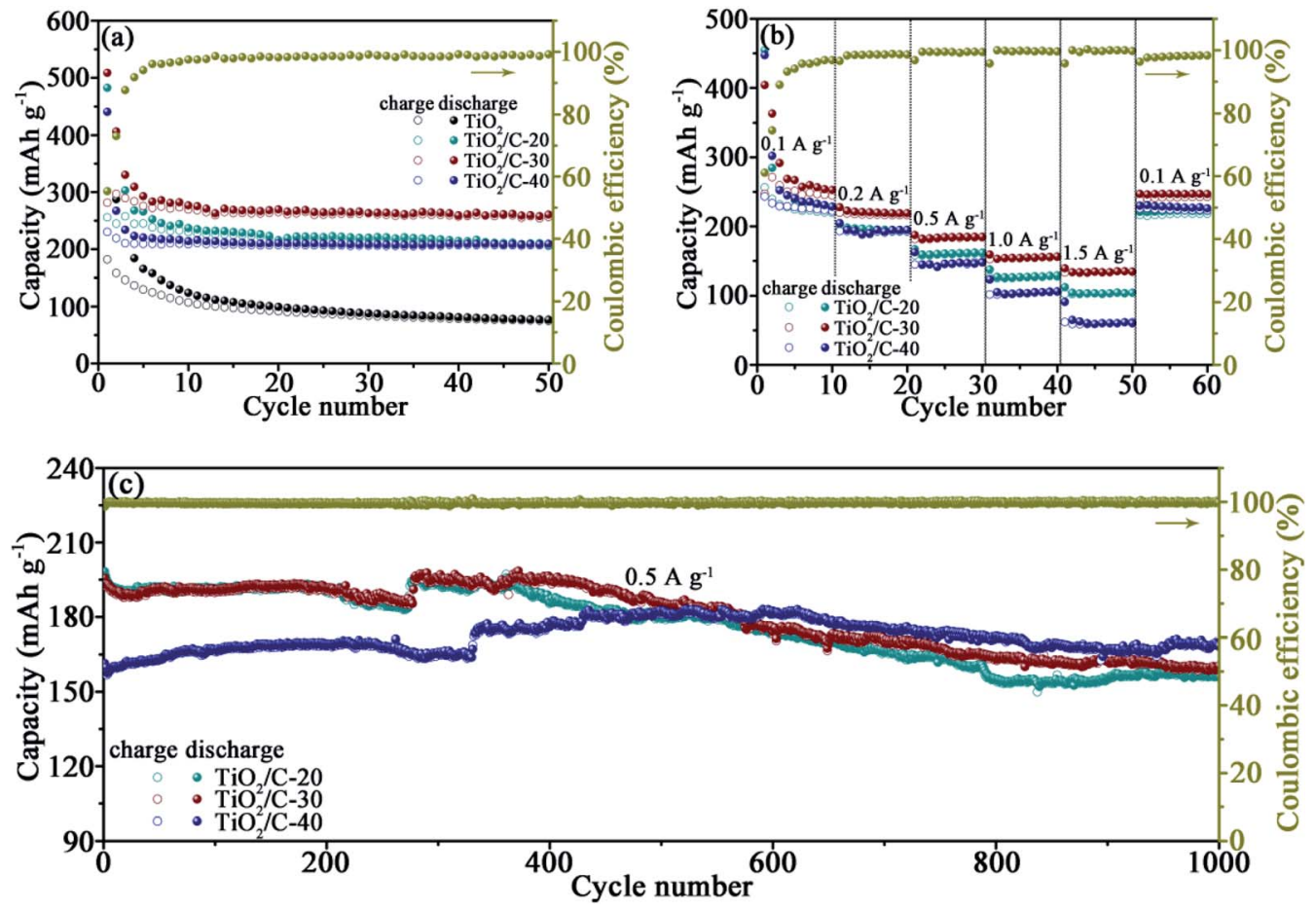

Fig. 4 (a) Cycling performance of $\mathrm{TiO}_{2}$ and $\mathrm{TiO}_{2} / \mathrm{C}$ at $0.1 \mathrm{~A} \mathrm{~g}^{-1}$, (b) rate performance of $\mathrm{TiO}_{2} / \mathrm{C}$, (c) cycling performance of $\mathrm{TiO}_{2} / \mathrm{C}$ at $0.5 \mathrm{~A} \mathrm{~g}$.

plane of anatase $\mathrm{TiO}_{2}$. Carbon coating about 2-3 carbon layers in thickness is discernible on the surface of $\mathrm{TiO}_{2}$ particles. The coating for $\mathrm{TiO}_{2} / \mathrm{C}-30$ is uniform (Fig. 3d), yet is discontinuous for $\mathrm{TiO}_{2} / \mathrm{C}-20$ because the carbon content is too low to fully cover the $\mathrm{TiO}_{2}$ particles (Fig. 3b), while for $\mathrm{TiO}_{2} / \mathrm{C}-40$, besides the unintermitted few-layered carbon, some amorphous carbon presents among the particles owing to the higher carbon content (Fig. 3f). The uniform and thin carbon coating could facilitate electron transfer, compensating for the poor electronic conductivity of $\mathrm{c}^{-\mathrm{TiO}_{2}}$. In addition, the carbon layer is also conducive to maintaining the stability of the structure, ${ }^{26}$ thus the structure will not easy to be destroyed during the $\mathrm{Li}^{+}$ shuttle, which is beneficial to improving the electrochemical performance of $\mathrm{c}-\mathrm{TiO}_{2}$.

\subsection{Electrochemical performance assessment}

The electrochemical performance of $\mathrm{TiO}_{2} / \mathrm{C}$ was firstly assessed by galvanostatically discharging/charging at $0.1 \mathrm{~A} \mathrm{~g}^{-1}$ with the active substance of about $1.7-2.3 \mathrm{mg} \mathrm{cm} \mathrm{cm}^{-2}$ on each electrode (Fig. 4a). The initial coulombic efficiencies (CE) are $26.2 \%$, $53.0 \%, 55.3 \%$ and $52.2 \%$ for $\mathrm{TiO}_{2}, \mathrm{TiO}_{2} / \mathrm{C}-20, \mathrm{TiO}_{2} / \mathrm{C}-30$ and
$\mathrm{TiO}_{2} / \mathrm{C}-40$, respectively, indicative of the enhanced $\mathrm{CE}$ after coating carbon derived from CA. The formation of SEI films in the 1st cycle is responsible for the low CE. Except for the initial cycles, the $\mathrm{CE}$ is almost close to $100 \%$, conducive to maintaining good cycling stability. After the initial several cycles, the capacities of the products tend to be stable, achieving lithiation capacities of 74.9, 205.7, 256.6 and $206.8 \mathrm{~mA} \mathrm{~h} \mathrm{~g}^{-1}$ after the 50th cycle for $\mathrm{TiO}_{2}, \mathrm{TiO}_{2} / \mathrm{C}-20, \mathrm{TiO}_{2} / \mathrm{C}-30$ and $\mathrm{TiO}_{2} / \mathrm{C}-40$, respectively. The capacity of $\mathrm{TiO}_{2} / \mathrm{C}$ is evidently higher than that of the bare $\mathrm{TiO}_{2}$, because the thin carbon coating could separate the $\mathrm{TiO}_{2}$ particles from electrolyte, preventing some side reactions and thus meliorating the electrochemical performance of $\mathrm{c}-\mathrm{TiO}_{2}$.

To understand the structural stability with cycling, the XRD patterns of $\mathrm{TiO}_{2} / \mathrm{C}-30$ were acquired before cycling and after 100 charge/discharge cycles at $0.1 \mathrm{~A} \mathrm{~g}^{-1}$ (Fig. S1 $\dagger$ ). Apparently, the structure after 100 cycles is identical to that prior to cycling with the $\mathrm{Cu}$ diffractions as a reference.

Rate capabilities were tested at $0.1,0.2,0.5,1.0,1.5$ and $0.1 \mathrm{~A} \mathrm{~g}^{-1}$ for every 10 cycles (Fig. 4b), the average capacity at each current density and the capacity retention relative to the capacity at the initial $0.1 \mathrm{~A} \mathrm{~g}^{-1}$ are summarized in Table 1 for

Table 1 Average lithiation capacities $\left(\mathrm{mA} \mathrm{h} \mathrm{g}^{-1}\right)$ and capacity retention (\%) at diverse current densities $\left(\mathrm{A} \mathrm{g}^{-1}\right)$

Capacities/capacity retention at varied current densities

\begin{tabular}{|c|c|c|c|c|c|c|}
\hline Samples & 0.1 & 0.2 & 0.5 & 1.0 & 1.5 & 0.1 \\
\hline $\mathrm{TiO}_{2} / \mathrm{C}-20$ & $221.3 / 100$ & 193.1/87.3 & $160.4 / 72.5$ & $127.2 / 57.5$ & $102.8 / 46.5$ & $218.7 / 98.8$ \\
\hline $\mathrm{TiO}_{2} / \mathrm{C}-30$ & $245.8 / 100$ & $216.6 / 88.1$ & $183.3 / 74.6$ & $154.4 / 62.8$ & $133.7 / 54.4$ & $242.6 / 98.7$ \\
\hline $\mathrm{TiO}_{2} / \mathrm{C}-40$ & $224.8 / 100$ & $191.1 / 85.0$ & $147.5 / 65.6$ & $105.3 / 46.8$ & $60.4 / 26.9$ & 224.1/99.7 \\
\hline
\end{tabular}


Table 2 Performance comparison of $\mathrm{TiO}_{2} / \mathrm{C}-30$ with other modified $\mathrm{TiO}_{2}$

\begin{tabular}{|c|c|c|c|}
\hline Electrode state & $\begin{array}{l}\text { Capacity at low } \\
\text { current rate }\end{array}$ & $\begin{array}{l}\text { Capacity at high } \\
\text { current rate }\end{array}$ & $\begin{array}{l}\text { Capacity/current rate/ } \\
\text { cycle number }\end{array}$ \\
\hline Nitrogen rich carbon coated $\mathrm{TiO}_{2}$ nanoparticles ${ }^{27}$ & $303 / 0.1 \mathrm{C}$ & $87 / 10 \mathrm{C}$ & $136 / 5 \mathrm{C} / 500$ \\
\hline N-doped hollow urchin-like anatase $\mathrm{TiO}_{2} @ \mathrm{C}$ composite ${ }^{29}$ & $165 / 1 \mathrm{C}$ & $111 / 10 \mathrm{C}$ & - \\
\hline Carbon@mesoporous $\mathrm{TiO}_{2}$ nanocrystalline@carbon ${ }^{30}$ & $244 / 0.1 \mathrm{C}$ & $115 / 5 \mathrm{C}$ & $191 / 0.2 C / 200$ \\
\hline $\mathrm{TiO}_{2} / \mathrm{C}-30$ (this work) & $245 / 100 \mathrm{~mA} \mathrm{~g}^{-1}$ & $133 / 1500 \mathrm{~mA} \mathrm{~g}^{-1}$ & $160 / 500 \mathrm{~mA} \mathrm{~g}^{-1} / 1000$ \\
\hline
\end{tabular}

intuitive comparison. $\mathrm{TiO}_{2} / \mathrm{C}-30$ exhibits not only the highest specific capacity but also the highest capacity retention at each current density, demonstrating the superior rate capabilities to the other carbon-coated products. The inferior rate performance of $\mathrm{TiO}_{2} / \mathrm{C}-20$ is related to the discontinuous carbon layers, while that of $\mathrm{TiO}_{2} / \mathrm{C}-40$ to the redundant carbon besides the carbon layers. When the current density returned to $0.1 \mathrm{~A} \mathrm{~g}^{-1}$ after the rate performance test, the capacity recovered to similar values to that at the initial $0.1 \mathrm{~A} \mathrm{~g}^{-1}$, denoting the excellent performance stability of $\mathrm{TiO}_{2} / \mathrm{C}$.

The cells were continued cycling at $0.5 \mathrm{~A} \mathrm{~g}^{-1}$ for exploring the cyclability (Fig. 4c). After 1000 cycles, the capacity is 156.1, 160.0 and $168.2 \mathrm{~mA} \mathrm{~h} \mathrm{~g}{ }^{-1}$ for $\mathrm{TiO}_{2} / \mathrm{C}-20, \mathrm{TiO}_{2} / \mathrm{C}-30$ and $\mathrm{TiO}_{2} / \mathrm{C}-40$, respectively, further confirming the excellent cycling stability after forming the thin carbon layers derived from CA.

The performance of $\mathrm{TiO}_{2} / \mathrm{C}-30$ was also compared with other modified $\mathrm{TiO}_{2}$ in literature (Table 2). With respect to the highly pure $\mathrm{TiO}_{2}$ derived from tetraethyl orthotitanate, ${ }^{27}$ tetra-n-butyl titanate ${ }^{28}$ titanium isopropoxide ${ }^{29,30}$ as well as modified by other carbon materials, $\mathrm{TiO}_{2} / \mathrm{C}-30$ reveals the performance comparable to that in the literature despite the simply fabrication of $\mathrm{TiO}_{2} / \mathrm{C}-30$ by employing the cheap raw materials of c$\mathrm{TiO}_{2}$ and CA.

\subsection{Electrochemical reaction analysis}

CV profiles were measured to compare the lithiation/ delithiation of $\mathrm{TiO}_{2}$ and $\mathrm{TiO}_{2} / \mathrm{C}$ (Fig. 5). The analogous plots manifest the similar reactions occurred in $\mathrm{TiO}_{2} / \mathrm{C}$ to those in $\mathrm{TiO}_{2}$. The lithiation/delithiation potentials around 1.5/2.4 V associate with the reaction $\mathrm{TiO}_{2}+x \mathrm{Li}^{+}+x e^{-} \leftrightarrow \mathrm{Li}_{x} \mathrm{TiO}_{2}(0 \leq x \leq$ 1). ${ }^{31}$ The cathodic peak around $0.7 \mathrm{~V}$ in the 1 st cycle is related to the formation of the SEI films, which disappears in the subsequent cycles. The difference $(\Delta V)$ between the anodic $\left(V_{\mathrm{a}}\right) /$ cathodic potentials $\left(V_{\mathrm{c}}\right)$ for the initial three $\mathrm{CV}$ cycles are given in Table 3, which reflects the polarization of the electrode materials to a certain degree. Roughly, the $\Delta V$ value for $\mathrm{TiO}_{2}$ is larger than those for $\mathrm{TiO}_{2} / \mathrm{C}$ with the same cycle due to the poor
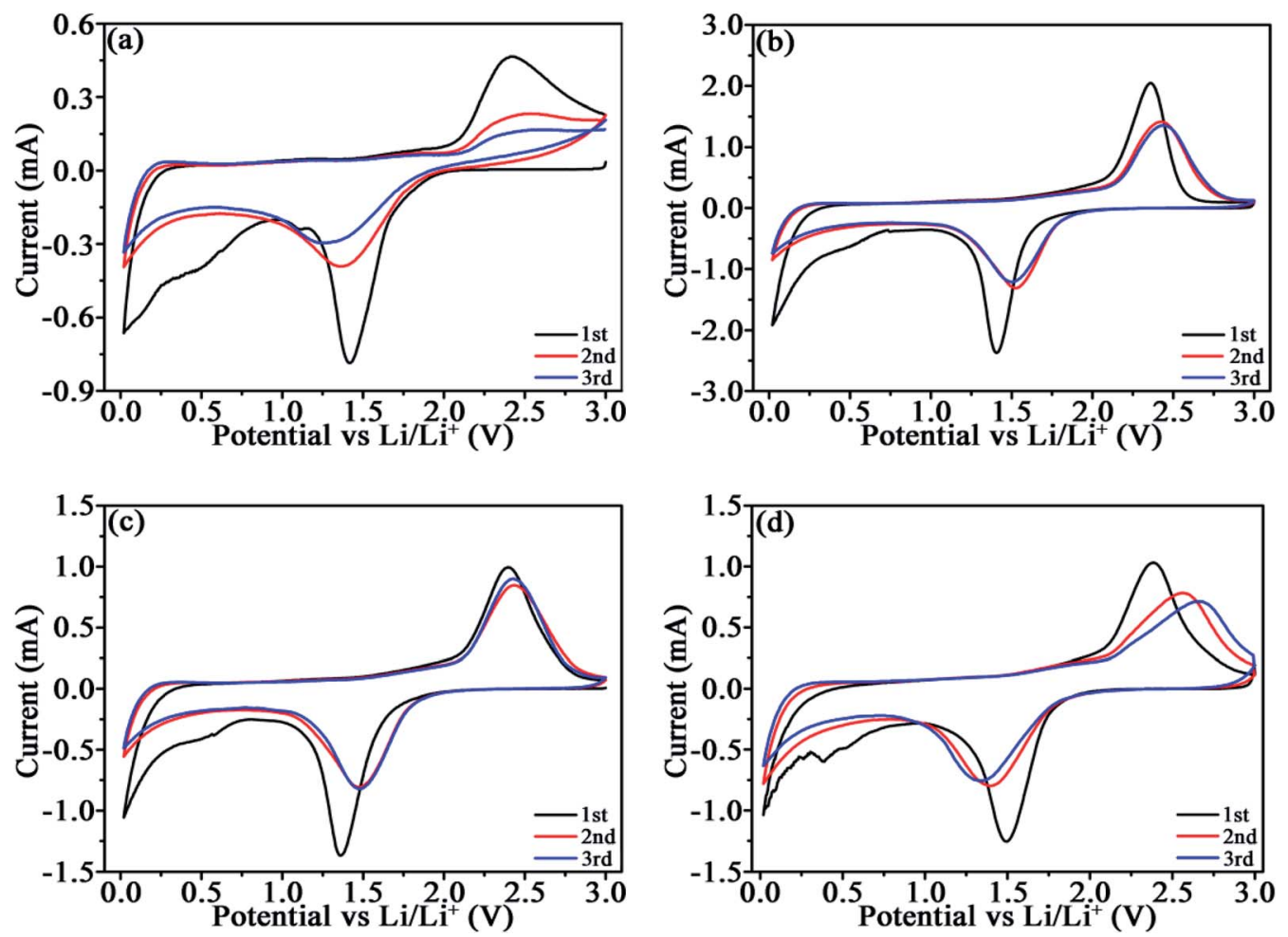

Fig. $5 \mathrm{CV}$ plots of $\mathrm{TiO}_{2}$ (a), $\mathrm{TiO}_{2} / \mathrm{C}-20$ (b), $\mathrm{TiO}_{2} / \mathrm{C}-30$ (c), and $\mathrm{TiO}_{2} / \mathrm{C}-40$ (d) at $0.3 \mathrm{mV} \mathrm{s}$. 
Table 3 Difference between the anodic and cathodic potentials for the first three CV cycles

\begin{tabular}{|c|c|c|c|c|c|c|c|c|c|}
\hline \multirow[b]{2}{*}{ Samples } & \multicolumn{3}{|c|}{ 1st cycle } & \multicolumn{3}{|c|}{ 2nd cycle } & \multicolumn{3}{|c|}{ 3rd cycle } \\
\hline & $V_{\mathrm{a}}$ & $V_{\mathrm{c}}$ & $\Delta V$ & $V_{\mathrm{a}}$ & $V_{\mathrm{c}}$ & $\Delta V$ & $V_{\mathrm{a}}$ & $V_{\mathrm{c}}$ & $\Delta V$ \\
\hline $\mathrm{TiO}_{2}$ & 2.41 & 1.42 & 0.99 & 2.49 & 1.37 & 1.12 & 2.67 & 1.28 & 1.39 \\
\hline $\mathrm{TiO}_{2} / \mathrm{C}-20$ & 2.37 & 1.41 & 0.96 & 2.43 & 1.53 & 0.90 & 2.44 & 1.51 & 0.93 \\
\hline $\mathrm{TiO}_{2} / \mathrm{C}-30$ & 2.40 & 1.36 & 1.04 & 2.43 & 1.48 & 0.95 & 2.43 & 1.48 & 0.95 \\
\hline $\mathrm{TiO}_{2} / \mathrm{C}-40$ & 2.39 & 1.49 & 0.90 & 2.56 & 1.40 & 1.16 & 2.66 & 1.35 & 1.3 \\
\hline
\end{tabular}

electronic conductivity of $\mathrm{c}-\mathrm{TiO}_{2}$. The $\Delta V$ for $\mathrm{TiO}_{2} / \mathrm{C}-20$ and $\mathrm{TiO}_{2} / \mathrm{C}-30$ is comparatively stable within the three cycles, while that for $\mathrm{TiO}_{2} / \mathrm{C}-40$ increases with cycling, because carbon materials usually exhibit inferior Li-ion conductivity, meanwhile, the redundant porous carbon results in more SEI films and thus elevated electrical resistance owing to the insulating feature of the SEI films.

\subsection{EIS analysis}

EIS were measured after cycling the cells for 50 times at $0.1 \mathrm{~A} \mathrm{~g}^{-1}$ to further recognize the effect of carbon on the electrochemical kinetics (Fig. 6). In the equivalent circuit fitting to the EIS (Fig. 6a), $R_{\mathrm{S}}$ stands for the electrolyte resistance, $R_{\mathrm{SEI}}$ for the SEI film resistance (acquired by the semicircle diameter in high frequency region ${ }^{32}$ ), $R_{\mathrm{ct}}$ for the charge transfer resistance, CPE for the constant phase elements relevant to interfacial capacitance, and $Z_{\mathrm{w}}$ for the Warburg impedance associating with $\mathrm{Li}^{+}$diffusion dynamics. Apparently, the fitting curves almost overlap with the experimental ones (more details at high frequency are displayed in Fig. 6b), corroborating the validity of the equivalent circuit. The data acquired from the fitting plots are collected in Table 4 . The total resistance $R_{\mathrm{T}}=\left(R_{\mathrm{S}}+R_{\mathrm{SEI}}+R_{\mathrm{ct}}\right)$ for $\mathrm{TiO}_{2} / \mathrm{C}$ is significantly smaller than that for $\mathrm{TiO}_{2}$, demonstrating the markedly enhanced electronic conductivity by coating the thin carbon layers. ${ }^{33}$ However, $\mathrm{TiO}_{2} / \mathrm{C}-40$ exhibits higher $R_{\mathrm{SEI}}, R_{\mathrm{ct}}$, and $R_{\mathrm{T}}$ than $\mathrm{TiO}_{2} / \mathrm{C}-30$, because the redundant carbon in $\mathrm{TiO}_{2} / \mathrm{C}-40$ gives rise to more SEI films due to the loose porous structure. The SEI film is favorable for Li-ion transfer yet unfavorable for electron migration, resulting in the increased $R_{\mathrm{SEI}}, R_{\mathrm{ct}}$ and $R_{\mathrm{T}}{ }^{34}$

Furthermore, $\mathrm{Li}^{+}$diffusion coefficient $(D)$ was calculated by the formula $I_{\mathrm{p}}=2.69 \times 10^{5} n^{3 / 2} A D^{1 / 2} \nu^{1 / 2} \Delta C_{0},{ }^{35}$ where $I_{\mathrm{p}}$ - peak
Table 4 Impedance values acquired from fitted EIS plots

\begin{tabular}{llrrr}
\hline Sample & $R_{\mathrm{S}}(\Omega)$ & $R_{\text {SEI }}(\Omega)$ & $R_{\text {ct }}(\Omega)$ & $R_{\mathrm{T}}(\Omega)$ \\
\hline $\mathrm{TiO}_{2}$ & 7.1 & 500.7 & 3649.0 & 4156.8 \\
$\mathrm{TiO}_{2} / \mathrm{C}-20$ & 5.7 & 34.5 & 120.7 & 160.9 \\
$\mathrm{TiO}_{2} / \mathrm{C}-30$ & 6.6 & 50.2 & 61.8 & 118.6 \\
$\mathrm{TiO}_{2} / \mathrm{C}-40$ & 6.3 & 201.7 & 299.6 & 507.6
\end{tabular}

Table 5 Peak current for the third CV cycle and other parameters for calculating the $D$ value

\begin{tabular}{lllllll}
\hline Samples & $I_{\mathrm{p}}(\mathrm{mA})$ & $a(\AA)$ & $b(\AA)$ & $c(\AA)$ & $\Delta C_{0}\left(\mathrm{~mol} \mathrm{~cm}^{-3}\right)$ & $D\left(\mathrm{~cm}^{2} \mathrm{~S}^{-1}\right)$ \\
\hline $\mathrm{TiO}_{2}$ & 0.17 & 3.784 & 3.784 & 9.515 & 0.0244 & $9.45 \times 10^{-13}$ \\
$\mathrm{TiO}_{2} / \mathrm{C}-20$ & 1.35 & 3.784 & 3.784 & 9.515 & 0.0244 & $5.96 \times 10^{-11}$ \\
$\mathrm{TiO}_{2} / \mathrm{C}-30$ & 0.90 & 3.784 & 3.784 & 9.515 & 0.0244 & $2.65 \times 10^{-11}$ \\
$\mathrm{TiO}_{2} / \mathrm{C}-40$ & 0.71 & 3.784 & 3.784 & 9.515 & 0.0244 & $1.64 \times 10^{-11}$ \\
\hline
\end{tabular}

current (taking the anodic peak of the stable 3rd CV cycle in Fig. 5 as an example), $\Delta C_{0}$ - change of $\mathrm{Li}^{+}$concentration during discharging/charging (listed in Table 5), $n=1$ for $\mathrm{TiO}_{2}, A=$ $1.5386 \mathrm{~cm}^{2}$ and $\nu=3 \times 10^{-4} \mathrm{~V} \mathrm{~s}^{-1}$. From the calculated $D$ values in Table 5, the thin carbon coating brings about the enhancement in ionic conductivity more than one order of magnitude. However, the conductivity decreases slightly with increasing the carbon content due to the poor Li-ion conductivity of carbon materials.

Comprehensively considering the electronic and ionic conductivities, the appropriate carbon content to form uniform thin layers (say $\mathrm{TiO}_{2} / \mathrm{C}-30$ ) is essential for $\mathrm{c}-\mathrm{TiO}_{2}$ to achieve the optimized electrochemical performance.

\subsection{Discussion}

The performance of the carbon-coated c- $-\mathrm{TiO}_{2}$ was discussed by combining the TEM, EIS, TGA, and CV results in this work with that reported in the literature available, ${ }^{17,18,36}$ as summarized in Table 6. Although the interaction with carbon could bring about great improvement in electrochemical performance of c- $\mathrm{TiO}_{2}$, the performance is still affected by several factors, such as the carbon source, carbonization temperature and resultant carbon content. When c- $\mathrm{TiO}_{2}$ was calcined at $450{ }^{\circ} \mathrm{C}$ with the carbon
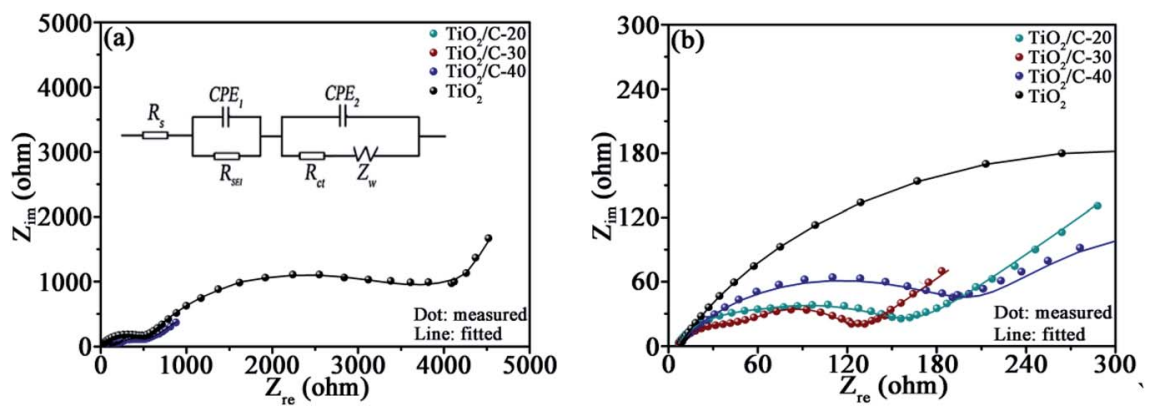

Fig. 6 (a) EIS and the corresponding fitting curves (the inset is the equivalent circuit fitting to the EIS of $\mathrm{TiO}_{2} / \mathrm{C}$ ), (b) the enlarged EIS at high frequency. 
Table 6 Data comparison for $\mathrm{TiO}_{2} / \mathrm{C}-30$ with those in the literature for $\mathrm{c}-\mathrm{TiO}_{2}$-concerned anodes (unit: capacity $-\mathrm{mA} \mathrm{h} \mathrm{g}{ }^{-1}$, current density $-\mathrm{A} \mathrm{g}^{-1}$, capacity retention $-\%$, temperature $\left.-{ }^{\circ} \mathrm{C}, \mathrm{CE}-\%\right)$

\begin{tabular}{llllll}
\hline Carbon source & $\begin{array}{l}\text { Carbonization } \\
\text { temperature }\end{array}$ & $\begin{array}{l}\text { Carbon } \\
\text { content }\end{array}$ & $\begin{array}{l}\text { Capacity at low rate/ } \\
\text { initial CE }\end{array}$ & $\begin{array}{l}\text { Capacity at high rate/ } \\
\text { capacity retention }\end{array}$ & $\begin{array}{l}\text { Capacity at } 0.5 \text { A g }{ }^{-1} \text { after cycling/ } \\
\text { cycle number }\end{array}$ \\
\hline Sucrose $^{36}$ & 450 & 1.9 & $231(0.03)$ & $130.0(0.3)$ & $203.4 / 250$ \\
Glucose $^{17}$ & 750 & 11.7 & $274.9(0.1) / 47.1$ & $100.7(1.6) / 36.6$ & $140.2 / 1000$ \\
Pitch $^{18}$ & 750 & 26.6 & $326.8(0.1) / 46.6$ & $162.5(1.6) / 49.7$ & $155.8 / 800$ \\
Pitch $^{37}$ & 900 & 10.3 & $180.7(0.1) / 40.5$ & $71.6(1.6) / 39.6$ & $160.0 / 1000$ \\
Citric acid & 750 & 2.98 & $245.8(0.1) / 55.3$ & $133.7(1.5) / 54.4$ &
\end{tabular}

precursor of sucrose, ${ }^{36}$ the carbon $/ \mathrm{TiO}_{2}$ nanocomposites only revealed better performance at low current rate because of the low carbonization temperature. When the sintering temperature was raised to $750^{\circ} \mathrm{C}$ using glucose as the carbon precursor, both the capacity and rate performance were further ameliorated due to the thorough removal of the residual $\mathrm{SO}_{4}{ }^{2-}$ in c$\mathrm{TiO}_{2}$. When employing pitch as the carbon source, ${ }^{18}$ the products calcined at $750{ }^{\circ} \mathrm{C}$ demonstrated high capacity, outstanding rate capabilities and cyclability. However, if the carbonization temperature was raised to $900{ }^{\circ} \mathrm{C},{ }^{37}$ the performance decreases despite the amelioration in electronic conductivity by introducing $\mathrm{Ti}_{9} \mathrm{O}_{17}$ yet with the reduction in active components. Consequently, compared to the performance of $\mathrm{c}-\mathrm{TiO}_{2}$ in the literature, $\mathrm{TiO}_{2} / \mathrm{C}-30$ demonstrates higher initial CE, superior rate performance and cyclability.

With respect to the carbon precursors of sucrose, glucose and pitch, a protrudent feature of CA lies in the carboxyl groups which could strongly interact with $\mathrm{TiO}_{2}$ to form self-assembled carboxylate monolayers on the surface of $\mathrm{TiO}_{2} \cdot{ }^{19}$ The highaffinity adsorption is conducive to yielding uniform fewlayered carbon coating during carbonization, thus not only meliorating the electronic conductivity of $\mathrm{TiO}_{2}$ but also avoiding the reduction in ionic conductivity caused by the thick carbon layer and redundant carbon. So the few-layered carbon derived from CA is greatly different from the carbon yielded by sucrose, glucose and pitch. The carbon produced by glucose and sucrose usually exhibits porous structure, and the c- $\mathrm{TiO}_{2}$ particles are more like embedding in the porous carbon instead forming carbon layers on the surface of $\mathrm{c}-\mathrm{TiO}_{2}$ particles. Carbon-coated c- $-\mathrm{TiO}_{2}$ could be obtained using pitch as the carbon precursor, but the content of pitch is frequently high to form the full carbon coating around the $\mathrm{c}-\mathrm{TiO}_{2}$ particles due to the poor interaction between pitch and $\mathrm{c}-\mathrm{TiO}_{2}$, inevitably yielding some redundant loose carbon. As revealed by EIS, the redundant carbon will lead to more SEI films and elevated SEI resistance (Fig. 6), as well as decreased ionic conductivity owing to the inferior Li-ion conductivity of carbon materials (Table 5). As a consequence, the uniform few-layered carbon coating derived from the intense interaction between $\mathrm{TiO}_{2}$ and CA simultaneous meliorates the electronic and ionic conductivities of c$\mathrm{TiO}_{2}$, giving rise to the markedly enhanced performance. This new strategy to achieve uniform and thin carbon coating on the c-TiO ${ }_{2}$ particles might be extended to other Ti-containing oxides by employing other carbon sources with carboxyl groups for optimizing the comprehensive electrochemical performance.

\section{Conclusions}

In summary, uniform thin carbon coating about 2-3 carbon layers in thickness could be easily formed on the $\mathrm{c}^{-\mathrm{TiO}_{2}}$ particles by adopting CA as the carbon source followed by carbonizing the mixture at $750{ }^{\circ} \mathrm{C}$. Herein the high-affinity adsorption of $\mathrm{TiO}_{2}$ for carboxyl groups to form self-assembled carboxylate monolayers on the surface of $\mathrm{TiO}_{2}$ is conducive to yielding the uniform and thin carbon layers during carbonization which could further endow the $\mathrm{c}-\mathrm{TiO}_{2}$ with the enhanced electronic and ionic conductivities, attenuated polarization, and thus the elevated capacity and excellent long-term cycling stability. The strategy might be extended to other Ti-containing oxides by employing other carbon sources with carboxyl groups for achieving uniform few-layered carbon coating to optimize the performance. Moreover, the simply processing with environmental benignity as well as the low cost carbon source of CA allows the carbon coating strategy applicable in industrial production of $\mathrm{c}-\mathrm{TiO}_{2}$ anodes for LIBs.

\section{Conflicts of interest}

There are no conflicts to declare.

\section{Acknowledgements}

This work was supported by project ZR2019MEM029 of Natural Science Foundation of Shandong Province, PR China.

\section{References}

1 W. Wen, J.-M. Wu, Y.-Z. Jiang, S.-L. Yu, J.-Q. Bai, M.-H. Cao and J. Cui, Sci. Rep., 2015, 5, 11804.

2 G.-N. Zhu, Y.-G. Wang and Y.-Y. Xia, Energy Environ. Sci., 2012, 5, 6652-6667.

3 J. Zhang, X. Yan, J. Zhang, W. Cai, Z. Wu and Z. Zhang, J. Power Sources, 2012, 198, 223-228.

4 Z. Chen, I. Belharouak, Y. K. Sun and K. Amine, Adv. Funct. Mater., 2013, 23, 959-969.

5 Y.-M. Jiang, K.-X. Wang, X.-X. Guo, X. Wei, J.-F. Wang and J.-S. Chen, J. Power Sources, 2012, 214, 298-302.

6 M. Wagemaker, G. J. Kearley, A. A. van Well, H. Mutka and F. M. Mulder, J. Am. Chem. Soc., 2003, 125, 840-848.

7 Z. Ali, S. N. Cha, J. I. Sohn, I. Shakir, C. Yan, J. M. Kim and D. J. Kang, J. Mater. Chem., 2012, 22, 17625-17629. 
8 T. Song, H. Han, H. Choi, J. W. Lee, H. Park, S. Lee, W. I. Park, S. Kim, L. Liu and U. Paik, Nano Res., 2015, 7, 491-501.

9 X. Chen and S.-S. Mao, Chem. Rev., 2007, 107, 2891-2959.

10 W. Li, F. Wang, Y. Liu, J. Wang, J. Yang, L. Zhang, A. A. Elzatahry, D. M. Aldhayan, Y. Xia and D. Zhao, Nano Lett., 2015, 15, 2186-2193.

11 L. Zhao, S. Wang, F. Pan, Z. Tang, Z. Zhang, S. Zhong and J. Zhang, J. Mater. Chem. A, 2018, 6, 11688-11693.

12 G. D. Park, J. H. Hong, J. K. Lee and Y. C. Kang, Nanoscale, 2019, 11, 631-638.

13 C. Wang, L. Wu, H. Wang, W. Zuo, Y. Li and J. Liu, Adv. Funct. Mater., 2015, 25, 3524-3533.

14 J.-Y. Liao, D. Higgins, G. Lui, V. Chabot, X. Xiao and Z. Chen, Nano Lett., 2013, 13, 5467-5473.

15 Y. Wu, C. Zhu, L. Shu, J. Duan, D. Wei, J. Xu, Z. Zhu, L. Li, Z. Peng and Z. Chen, Appl. Surf. Sci., 2019, 489, 528-537.

16 C. Zhao, L. Liu, Q. Zhang, J. Rogers, H. Zhao and Y. Li, Electrochim. Acta, 2015, 155, 288-296.

17 L.-Y. Wang, Y. Wu, J.-P. Han, B. Zhang, X. Bai, Y.-X. Qi, N. Lun, Y.-M. Cao and Y.-J. Bai, Electrochim. Acta, 2017, 245, 186-192.

18 L.-Y. Wang, X. Bai, Y. Wu, N. Lun, Y.-X. Qi and Y.-J. Bai, Electrochim. Acta, 2016, 212, 155-161.

19 J. Balajka, M. A. Hines, D. B. Wji, M. Komora, J. Pavelec, M. Schmid and U. Diebold, Science, 2018, 361, 786-789.

20 N. Venkatachalam, M. Palanichamy and V. Murugesan, J. Mol. Catal. A: Chem., 2007, 273, 177-185.

21 B. Naik, K. M. Parida and C. S. Gopinath, J. Phys. Chem. C, 2010, 114, 19473-19482.

22 G. Trettenhahn and A. Köberl, Electrochim. Acta, 2007, 52, 2716-2722.
23 K. Umemura, T. Ueda, S. S. Munawar and S. Kawai, J. Appl. Polym. Sci., 2011, 123, 1991-1996.

24 V. Swamy, A. Kuznetsov, L. S. Dubrovinsky, R. A. Caruso, D. G. Shchukin and B. C. Muddle, Phys. Rev. B: Condens. Matter Mater. Phys., 2005, 71, 184302.

25 W. Zhang, Y. He, M. Zhang, Z. Yin and Q. Chen, J. Phys. D: Appl. Phys., 2000, 33, 912-916.

26 T. Zhao, D. Zhu, W. Li, A. Li and J. Zhang, J. Power Sources, 2019, 439, 227027.

27 C. Senthil, T. Kesavan, A. Bhaumik, M. Yoshio and M. Sasidharan, Electrochim. Acta, 2017, 255, 417-427.

28 H. Luo, C. Xu, B. Wang, F. Jin, L. Wang, T. Liu, Y. Zhou and D. Wang, Electrochim. Acta, 2019, 313, 10-19.

29 Y. Xing, S. Wang, B. Fang, G. Song, D. P. Wilkinson and S. Zhang, J. Power Sources, 2018, 385, 10-17.

30 W. Yan, Y. Yuan, J. Xiang, Y. Wu, T. Zhang, S. Yin and S. Guo, Electrochim. Acta, 2019, 312, 119-127.

31 G. Nuspl, K. Yoshizawa and T. Yamabe, J. Mater. Chem., 1997, 7, 2529-2536.

32 M. S. Kim, B. Fang, J. H. Kim, D. Yang, K. K. Yun, T. S. Bae and J. S. Yu, J. Mater. Chem., 2011, 21, 19362-19367.

33 D. Wang, D. Choi, J. Li, Z. Yang, Z. Nie, R. Kou, D. Hu, C. Wang, L. V. Saraf and J. Zhang, ACS Nano, 2009, 3, 907914.

34 J. Wang, X.-M. Liu, H. Yang and X.-D. Shen, J. Alloys Compd., 2011, 509, 712-718.

35 A. J. Brad and L. R. Faulkner, Electrochemical methods: fundamentals and applications, vol. 2, Wiley-VCH, New York, 1980.

36 C. Zhao, L. Liu, Q. Zhang, J. Rogers, H. Zhao and Y. Li, Electrochim. Acta, 2015, 155, 288-296.

37 J.-X. Teng, R.-L. Bai, L.-Y. Wang and Y.-J. Bai, J. Alloys Compd., 2018, 762, 594-604. 